\title{
Tetrahydrobostrycin and 1-Deoxytetrahydrobostrycin, Two New Hexahydroanthrone Derivatives, from a Marine-derived Fungus Aspergillus sp.
}

\author{
Jinzhong Xu, Takahiro Nakazawa, Kazuyo Ukai, Hisayoshi Kobayashi, Remy E. P. Mangindaan, \\ Defny S. Wewengkang, Henki Rotinsulu, Michio Namikoshi
}

Received: March 18, 2008 / Accepted: June 14, 2008

(C) Japan Antibiotics Research Association

\begin{abstract}
Two new hexahydroanthrones, tetrahydrobostrycin (1) and 1-deoxytetrahydrobostrycin (2), were isolated from a marine-derived fungus Aspergillus sp. strain 05F 16 collected at the coral reef of Manado, Indonesia, together with bostrycin and abscisic acid. The structures of new compounds were determined on the basis of their spectral data. Compound 1 showed weak antibacterial activity against Staphylococcus aureus and Escherichia coli and $\mathbf{2}$ against $S$. aureus.
\end{abstract}

Keywords marine-derived fungus, Aspergillus sp., tetrahydrobostrycin, 1-deoxytetrahydrobostrycin, hexahydroanthrone, bostrycin, abscisic acid

\section{Introduction}

Marine-derived fungi have proven to be a prolific source of new bioactive secondary metabolites [1 3]. Diverse chemical structures with interesting biological activities, such as cytotoxicity against cancer cell lines, antimicrobial activity, and inhibition of specific enzyme activities, have been reported in scientific journals [1 3]. Therefore, we have further investigated bioactive secondary metabolites of marine-derived fungi isolated from tropical coral reefs and obtained two new hexahydroanthrone derivatives, 1,2,3,5,8,10-hexahydroxy-6-methoxy1,2,4,4a,9a,10-hexahydroanthracen-9-one (named as tetrahydrobostrycin, 1) and 2,3,5,8,10-pentahydroxy-6-<smiles>[Y6]Oc1cc(O)c2c(c1O)[C@H](O)[C@@H]1C[C@H](I)[C@@H](O)[C@H](P)[C@H]1C2=O</smiles>

tetrahydrobostrycin (1): $\mathrm{R}=\mathrm{OH}$ 1-deoxytetrahydrobostrycin (2): $\mathrm{R}=\mathrm{H}$<smiles>COC1=CC(=O)c2c(O)c3c(c(O)c2C1=O)C[C@@](C)(O)[C@H](O)[C@H]3O</smiles>

bostrycin (3)<smiles>CC1=CC(=O)CC(C)(C)[C@]1(C)/C=C/C(C)=C\C(=O)O</smiles>

abscisic acid (4)

Fig. 1 Structures of tetrahydrobostrycin (1), 1-deoxytetrahydrobostrycin (2), bostrycin (3), abscisic acid (4).

M. Namikoshi (Corresponding author), J. Xü, T. Nakazawa, K. Ukai: Tohoku Pharmaceutical University, Komatsushima, Aobaku, Sendai 981-8558, Japan, E-mail: mnami@tohoku-pharm.ac.jp H. Kobayashi: Institute of Molecular and Cellular Biosciences, The University of Tokyo, Bunkyo-ku, Tokyo 113-0032, Japan
R. E. P. Mangindaan, D. S. Wewengkang, H. Rotinsulu: Faculty of Fisheries and Marine Science, Sam Ratulangi University, Kampus Bahu, Manado 95115, Indonesia

${ }^{\dagger}$ Present address: Department of Chinese Medicine Science and Engineering, College of Pharmaceutical Sciences, Zhejiang University, Hangzhou 310058, People's Republic of China 
methoxy-1,2,4,4a,9a,10-hexahydroanthracen-9-one (named as 1-deoxytetrahydrobostrycin, 2), from Aspergillus sp. collected in Manado, Indonesia, together with a red pigment bostrycin (3) [4 10], and the plant hormone abscisic acid (4). We describe herein the isolation, structure elucidation, and biological activity of two new compounds 1 and 2.

\section{Materials and Methods}

\section{General Experimental Procedures}

NMR spectra were measured on a JEOL JNM-AL-400 or JNM-LA-600 NMR spectrometer in DMSO- $d_{6}\left(\delta_{\mathrm{H}} 2.49, \delta_{\mathrm{C}}\right.$ $39.5)$ or $\mathrm{CD}_{3} \mathrm{OD}\left(\delta_{\mathrm{H}} 3.30, \delta_{\mathrm{C}} 49.0\right)$. Mass spectra were obtained by a JEOL JMS-MS 700 mass spectrometer (EI or FAB mode with $m$-nitrobenzyl alcohol or glycerol as the matrix). UV and IR spectra were recorded on a Hitachi U3310 spectrophotometer and a Perkin-Elmer Spectrum One FT-IR spectrometer, respectively. Optical rotations were recorded with a JASCO DIP-370 digital polarimeter. HPLC was performed using a HITACHI Pump L-2130 equipped with a UV Detector L-2400.

\section{Producing Organism}

The fungus $05 \mathrm{~F} 16$ was isolated from an unidentified alga collected in the coral reef at Manado, Indonesia. The alga was smashed with sterile seawater in a mortar and the resulted liquid $(0.2 \mathrm{ml})$ was applied on an agar plate $(1 / 10$ YSA, 90\% seawater). The fungus grown on the agar plate was isolated and identified as Aspergillus sp. from the shapes and colors of conidia and mycelia. The strain 05F16 was cultured in twelve 500-ml Erlenmeyer-flasks containing each $150 \mathrm{ml}$ of $1 / 2 \mathrm{PD}$ medium (50\% natural seawater) [11] for about three weeks at $20^{\circ} \mathrm{C}$.

\section{Extraction and Isolation}

The culture broth of $05 \mathrm{~F} 16(1,800 \mathrm{ml})$ was filtered and extracted with EtOAc $(3 \times 900 \mathrm{ml})$. A portion $(100 \mathrm{mg})$ of the EtOAc extract $(520 \mathrm{mg})$ was subjected to HPLC separation (column, Pegasil ODS, $10 \mathrm{~mm} \times 250 \mathrm{~mm}$; flow rate, $2.0 \mathrm{ml} / \mathrm{minute}$; detection, UV $280 \mathrm{~nm}$ ) with $\mathrm{MeOH}$ $\mathrm{H}_{2} \mathrm{O}=52: 48$ to give compound $1(20.0 \mathrm{mg})$, abscisic acid $(4,12.0 \mathrm{mg})$, and a mixture of $\mathbf{2}$ and $\mathbf{3}(29.0 \mathrm{mg})$, which was

Table $1{ }^{1} \mathrm{H}-(600 \mathrm{MHz})$ and ${ }^{13} \mathrm{C}-(100 \mathrm{MHz}) \mathrm{NMR}$ data for compound 1

\begin{tabular}{ccll}
\hline C\# & ${ }^{13} \mathrm{C}(\delta)^{\mathrm{a}}$ & \multicolumn{1}{c}{${ }^{1} \mathrm{H}(\delta, \text { mult, } J \text { in Hz })^{\mathrm{a}}$} & \multicolumn{1}{c}{${ }^{1} \mathrm{H}(\delta, \text { mult, } J \text { in Hz })^{\mathrm{b}}$} \\
\hline 1 & 69.7 & $3.85, \mathrm{ddd}, 13.2,8.8,2.9$ & $4.07, \mathrm{dd}, 9.5,9.2$ \\
2 & 77.9 & $3.05, \mathrm{dd}, 8.8,5.4$ & $3.27, \mathrm{~d}, 9.2$ \\
3 & 70 & - & - \\
4 & 39.6 & $(a x) 1.30,. \mathrm{dd}, 13.2,12.5$ & $($ ax. $) 1.42, \mathrm{dd}, 13.6,11.7$ \\
& & $($ eq. $) 2.10, \mathrm{dd}, 13.2,3.9$ & $($ eq. $) 2.32, \mathrm{dd}, 13.6,3.7$ \\
$4 \mathrm{a}$ & 39.6 & $2.20, \mathrm{~m}, 12.5,9.8,9.3,3.9$ & $2.28, \mathrm{~m}, 13.2,11.7,9.5,3.7$ \\
5 & 137.5 & - & - \\
6 & 155.6 & - & - \\
7 & 99.2 & $6.49, \mathrm{~s}$ & - \\
8 & 157.2 & - & - \\
$8 \mathrm{a}$ & 108.1 & - & - \\
9 & 203.8 & - & $2.38, \mathrm{~s}, \mathrm{dd}, 13.2,9.5$ \\
$9 \mathrm{a}$ & 52.1 & $2.42, \mathrm{dd}, 13.2,9.3$ & $4.80, \mathrm{~d}, 9.5$ \\
10 & 71.8 & $4.76, \mathrm{dd}, 9.8,6.8$ & - \\
$10 \mathrm{a}$ & 127.7 & - & $1.31, \mathrm{~s}$ \\
11 & 27.1 & $1.15, \mathrm{~s}$ & $3.90, \mathrm{~s}$ \\
12 & 56 & $3.83, \mathrm{~s}$ & - \\
$1-\mathrm{OH}$ & - & $4.46, \mathrm{~d}, 2.9$ & - \\
$2-\mathrm{OH}$ & - & $4.56, \mathrm{~d}, 5.4$ & - \\
$3-\mathrm{OH}$ & - & $4.08, \mathrm{~s}$ & - \\
$5-\mathrm{OH}$ & - & $9.28, \mathrm{~s}$ & - \\
$8-\mathrm{OH}$ & - & $12.22, \mathrm{~s}$ & - \\
$10-\mathrm{OH}$ & - & $6.37, \mathrm{~d}, 6.8$ & - \\
\hline
\end{tabular}

${ }^{a}$ Measured in DMSO- $d_{6} .{ }^{b}$ Measured in $\mathrm{CD}_{3} \mathrm{OD}$. 
further separated by HPLC (same column) with $\mathrm{MeOH}$ $\mathrm{H}_{2} \mathrm{O}=38: 62$ to yield compound $2(6.8 \mathrm{mg})$ and bostrycin (3, $10.8 \mathrm{mg})$.

\section{Tetrahydrobostrycin}

$[\alpha]_{\mathrm{D}}^{18}-116.6^{\circ}(c 0.8, \mathrm{MeOH})$. UV $\lambda_{\max }^{\mathrm{MeOH}} \mathrm{nm}(\log \varepsilon) 244$ (3.97), 284 (3.88), 355 (3.63). IR $v_{\max }(\mathrm{KBr}) \mathrm{cm}^{-1} 3428$, 2978, 2928, 1627, 1495, 1443, 1385, 1281, 1245, 1204, $1157,1072,1053,1034 .{ }^{1} \mathrm{H}-\mathrm{NMR}\left(600 \mathrm{MHz}\right.$ in DMSO- $d_{6}$ and in $\mathrm{CD}_{3} \mathrm{OD}$ ) and ${ }^{13} \mathrm{C}-\mathrm{NMR}\left(100 \mathrm{MHz}\right.$ in DMSO- $\left.d_{6}\right)$ : see Table 1. High-resolution (HR) FAB-MS $m / z \quad 341.1232$ $\left[(\mathrm{M}+\mathrm{H})^{+}\right.$, Calcd for $\left.\mathrm{C}_{16} \mathrm{H}_{21} \mathrm{O}_{8}, 341.1236\right]$.

\section{1-Deoxytetrahydrobostrycin}

$[\alpha]_{\mathrm{D}}^{18}-69.3^{\circ}(c 0.4, \mathrm{MeOH}) . \mathrm{UV} \lambda_{\max }^{\mathrm{MeOH}} \mathrm{nm}(\log \varepsilon) 245$ (sh), 280 (3.28), 350 (3.01). IR $v_{\max }(\mathrm{KBr}) \mathrm{cm}^{-1} 3436$, 2976, 2924, 1630, 1498, 1441, 1385, 1278, 1226, 1201, $1152,1070,1054 .{ }^{1} \mathrm{H}-\mathrm{NMR}\left(600 \mathrm{MHz}\right.$ in DMSO- $d_{6}$ and in $\left.\mathrm{CD}_{3} \mathrm{OD}\right)$ and ${ }^{13} \mathrm{C}-\mathrm{NMR}\left(100 \mathrm{MHz}\right.$ in DMSO- $\left.d_{6}\right)$ : see Table 2. HRFAB-MS $m / z \quad 325.1296\left[(\mathrm{M}+\mathrm{H})^{+}\right.$, Calcd for $\left.\mathrm{C}_{16} \mathrm{H}_{21} \mathrm{O}_{7}, 325.1288\right]$.

\section{Antimicrobial Assay}

Two new compounds $\mathbf{1}$ and $\mathbf{2}$ were tested for antimicrobial activity against Staphylococcus aureus IAM 12544T (16 hours at $37^{\circ} \mathrm{C}$ ), Escherichia coli IAM 12119T (16 hours at $37^{\circ} \mathrm{C}$ ), Saccharomyces cerevisiae IAM $14383 \mathrm{~T}$ (40 hours at $25^{\circ} \mathrm{C}$ ), and Mucor hiemalis IAM 6088 (40 hours at $25^{\circ} \mathrm{C}$ ). Test compounds were dissolved in $\mathrm{MeOH}$ or $\mathrm{EtOH}$ and $40 \mu \mathrm{l}$ of each solution was absorbed on a disc $(8 \mathrm{~mm}$ in diameter; 25, 50, and $100 \mu \mathrm{g} / \mathrm{disc})$. After incubation, diameters of the inhibition zones were measured.

\section{Results and Discussion}

The producing fungus was isolated from an unidentified alga collected in the coral reef at Manado, Indonesia. The culture broth and EtOAc extract of strain 05F16 showed red color, and four chemical constituents $(\mathbf{1} \sim \mathbf{4})$ were isolated from the EtOAc extract. Compounds $\mathbf{1}$ and $\mathbf{2}$ showed a pale-yellow color, and $\mathbf{3}$ was a red pigment whose structure was assigned from its spectroscopic data and by comparison with the reported values for bostrycin [4 7].

Table $2{ }^{1} \mathrm{H}-(600 \mathrm{MHz})$ and ${ }^{13} \mathrm{C}-(100 \mathrm{MHz}) \mathrm{NMR}$ data for compound 2 in DMSO- $d_{6}$

\begin{tabular}{|c|c|c|c|}
\hline C\# & ${ }^{13} \mathrm{C}(\delta)^{\mathrm{a}}$ & ${ }^{1} \mathrm{H}(\delta, \text { mult, } J \text { in } \mathrm{Hz})^{\mathrm{a}}$ & ${ }^{1} \mathrm{H}(\delta, \text { mult, } J \text { in } \mathrm{Hz})^{\mathrm{b}}$ \\
\hline 1 & 29.2 & $\begin{array}{l}\text { (ax.) 1.48, ddd, 12.4, 12.2, } 12.0 \\
\text { (eq.) 2.05, ddd, 12.2, 5.6, } 4.0\end{array}$ & $\begin{array}{l}\text { (ax.) 1.66, ddd, 12.8, 12.1, } 11.7 \\
\text { (eq.) 2.29, ddd, 12.8, 4.4, } 4.0\end{array}$ \\
\hline 2 & 73.2 & $3.25, \mathrm{ddd}, 12.0,6.3,5.6$ & $3.44, d d, 11.7,4.4$ \\
\hline 3 & 69.4 & - & - \\
\hline 4 & 40.7 & $\begin{array}{l}\text { (ax.) } 1.20, \mathrm{dd}, 13.2,12.0 \\
\text { (eq.) } 2.15, \mathrm{dd}, 13.2,3.8\end{array}$ & $\begin{array}{l}\text { (ax.) 1.35, dd, 13.9, } 11.7 \\
\text { (eq.) 2.35, dd, 13.9, } 4.0\end{array}$ \\
\hline $4 a$ & 40.7 & $2.05, \mathrm{~m}, 12.2,12.0,10.0,3.8$ & $2.16, \mathrm{~m}, 12.8,11.7,10.3,4.0$ \\
\hline 5 & 137.6 & - & - \\
\hline 6 & 155.5 & - & - \\
\hline 7 & 99.2 & $6.48, s$ & $6.46, \mathrm{~s}$ \\
\hline 8 & 157.5 & - & - \\
\hline $8 a$ & 107.6 & - & - \\
\hline 9 & 202.7 & - & - \\
\hline $9 a$ & 45.8 & 2.44, ddd, $12.4,12.2,4.0$ & 2.40, ddd, $12.8,12.1,4.0$ \\
\hline 10 & 71.9 & 4.69, brd, 10.0 & $4.76, d, 10.3$ \\
\hline $10 a$ & 127.3 & - & - \\
\hline 11 & 26.9 & $1.15, \mathrm{~s}$ & $1.30, \mathrm{~s}$ \\
\hline 12 & 55.9 & $3.81, \mathrm{~s}$ & $3.89, \mathrm{~s}$ \\
\hline $2-\mathrm{OH}$ & - & $4.47, d, 6.3$ & - \\
\hline $3-\mathrm{OH}$ & - & $3.86, \mathrm{~s}$ & - \\
\hline $5-\mathrm{OH}$ & - & 9.49, br s & - \\
\hline 8-OH & - & $12.67, \mathrm{~s}$ & - \\
\hline $10-\mathrm{OH}$ & - & 6.51, brs & - \\
\hline
\end{tabular}

${ }^{\text {a }}$ Measured in DMSO- $d_{6} \cdot{ }^{b}$ Measured in $\mathrm{CD}_{3} \mathrm{OD}$. 
Compound 4 was identified as abscisic acid, the plant hormone, from its spectroscopic data. Bostrycin (3) was first isolated from Bostryconema alpestre [4, 5] and then from Nigrospora oryzae [8], Arthrinium phaeospermum [9], and Alternaria eichhorniae [10]. Antibacterial and phytotoxic activities have been described in these papers. The predominant tautomer and absolute configuration of bostrycin were determined as $\mathbf{3}$ by syntheses $[6,7]$.

Compound 1 showed the $(\mathrm{M}+\mathrm{H})^{+}$ion at $\mathrm{m} / \mathrm{z} 341.1232$ in the HRFAB mass spectrum. The molecular formula, $\mathrm{C}_{16} \mathrm{H}_{20} \mathrm{O}_{8}$, was deduced from the HRFAB-MS and NMR data (Table 1). The ${ }^{1} \mathrm{H}$ and ${ }^{13} \mathrm{C}$ signals of 1 were assigned by the analysis of $2 \mathrm{D}\left({ }^{1} \mathrm{H}-{ }^{1} \mathrm{H}\right.$ COSY, HMQC, and HMBC) and DEPT spectra. The ${ }^{13} \mathrm{C}-\mathrm{NMR}$ spectrum of $\mathbf{1}$ revealed the presence of 16 carbon signals ascribed to a methyl, a methoxy, a methylene, two methine, three hydroxymethine, a hydroxylated quaternary carbon atom, a carbonyl, and six aromatic carbons. Six $\mathrm{OH}$ signals were detected in the ${ }^{1} \mathrm{H}-$ NMR spectrum of 1 . The connectivity of 2-1-9a-4a-(4)-10 was determined from the ${ }^{1} \mathrm{H}-{ }^{1} \mathrm{H}$ COSY spectrum of $\mathbf{1}$, which also showed correlations between $\mathrm{H}-1$ and $1-\mathrm{OH}, \mathrm{H}-$ 2 and 2-OH, and $\mathrm{H}-10$ and 10-OH (Fig. 2). The skeletal structure of 1 was assigned by the interpretation of the HMBC data (Fig. 2).

The relative stereochemistry of $\mathbf{1}$ was determined from ${ }^{1} \mathrm{H}$ coupling constants and NOESY data. Relatively large coupling constants observed between $\mathrm{H}-1$ and $\mathrm{H}-2$ $(J=8.8 \mathrm{~Hz}$ ), H-1 and H-9a (13.2), H-4ax and H-4a (12.5), $\mathrm{H}-4 \mathrm{a}$ and H-9a (9.3), and H-4a and H-10 (9.8) suggested that the orientations of these hydrogens are axial or psudoaxial. These orientations were confirmed by the analysis of NOESY spectrum of $\mathbf{1}$. Key NOESY correlations were detected between $\mathrm{H}-1$ and $\mathrm{H}-4 \mathrm{a}, \mathrm{H}-2$ and H-4ax, H-2 and H-9a, H-4ax and H-9a, H-4ax and H-10, $\mathrm{H}-9 \mathrm{a}$ and $\mathrm{H}-10$, and $\mathrm{H}_{3}-11$ and $\mathrm{H}-4$ eq. Consequently, the
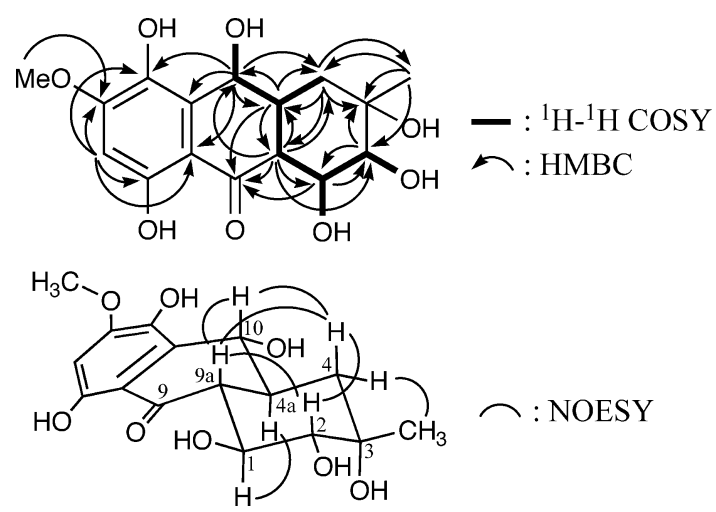

Fig. $2{ }^{1} \mathrm{H}^{-1} \mathrm{H}$ COSY, HMBC, and key NOESY correlations of compound $\mathbf{1}$ structure of 1 was assigned as shown in Fig. 1. Compound 1 was a tetrahydro-derivative of bostrycin (3) and named as tetrahydrobostrycin. The stereochemistry of $\mathbf{1}$ shown in Fig. 1 was illustrated according to the absolute structure of bostrycin (3) [7].

Compound 2 showed similar ${ }^{1} \mathrm{H}$ - and ${ }^{13} \mathrm{C}-\mathrm{NMR}$ spectra as those of 1, except for the lack of an $\mathrm{OH}$ group in the spectra of $\mathbf{2}$. The molecular formula of $\mathbf{2}$ was determined from HRFAB-MS and NMR data as $\mathrm{C}_{16} \mathrm{H}_{20} \mathrm{O}_{7}$, which corresponded to the difference of one oxygen $(16 \mathrm{Da})$ in the molecular formula (weight) between $\mathbf{2}$ and $\mathbf{1}$. Therefore, compound $\mathbf{2}$ was suggested to be a deoxy-derivative of $\mathbf{1}$. ${ }^{1} \mathrm{H}$ - and ${ }^{13} \mathrm{C}$-NMR data for $\mathbf{2}$ (Table 2) were assigned by the analysis of ${ }^{1} \mathrm{H}-{ }^{1} \mathrm{H}$ COSY, DEPT, HMQC, and HMBC spectra. The ${ }^{1} \mathrm{H}-{ }^{1} \mathrm{H}$ COSY spectrum of $\mathbf{2}$ revealed correlations between $\mathrm{H}-2$ and 2-OH, $\mathrm{H}-2$ and $\mathrm{H}_{2}-1, \mathrm{H}_{2}-1$ and $\mathrm{H}-9 \mathrm{a}, \mathrm{H}-9 \mathrm{a}$ and $\mathrm{H}-4 \mathrm{a}, \mathrm{H}-4 \mathrm{a}$ and $\mathrm{H}_{2}-4, \mathrm{H}-4 \mathrm{a}$ and $\mathrm{H}-10$, and $\mathrm{H}-10$ and $10-\mathrm{OH}$. The HMBC spectrum of 2 gave similar correlations that observed in the HMBC spectrum of 1. These NMR data clearly showed that the hydroxyl group at the $\mathrm{C}-1$ position in $\mathbf{1}$ was replaced by a hydrogen in 2. Coupling constants between $\mathrm{H}-1 \mathrm{ax}$ and $\mathrm{H}-2$ $(J=12.0 \mathrm{~Hz}), \mathrm{H}-1 \mathrm{ax}$ and H-9a (12.4), H-4ax and H-4a (12.0), H-4a and H-9a (12.2), and H-4a and H-10 (10.0) observed in the ${ }^{1} \mathrm{H}$-NMR spectrum of 2 were similar to those of 1. Moreover, NOESY correlations were detected between H-1ax and H-4a, H-2 and H-4ax, H-2 and H-9a, H-4ax and H-9a, H-4ax and H-10, H-9a and H-10, and $\mathrm{H}_{3}-11$ and $\mathrm{H}-4$ eq. Thus, the structure of 2 was assigned as a 1-deoxy derivative of $\mathbf{1}$ and named as 1deoxyteterahydrobostrycin (Fig. 1).

Compound $\mathbf{1}$ inhibited the growth of Staphylococcus aureus and Escherichia coli at $100 \mu \mathrm{g} / \mathrm{disc}$ with the inhibition zones of 15 and $9.2 \mathrm{~mm}$ in diameter, respectively. Compound 2 was active against $S$. aureus $(12 \mathrm{~mm}$ at $100 \mu \mathrm{g} / \mathrm{disc})$. The growth of Saccharomyces cerevisiae and Mucor hiemalis was not affected by these compounds at $100 \mu \mathrm{g} /$ disc. It is interesting that the presence of an $\mathrm{OH}$ group at C-1 is important for the antibacterial activity of $\mathbf{1}$ against $E$. coli, although the antibacterial activity of these compounds are very weak. The 5-deoxy derivative of $\mathbf{2}$ (tetrahydroaltersoranol B) has been isolated from a plant pathogenic fungus Alternaria solani [12, 13] and showed no apparent antimicrobial activity against Gram-positive bacteria at $50 \mu \mathrm{g} / \mathrm{ml}$ by the broth dilution method [13]. An epimer at the 10 position of $\mathbf{1}$ has recently been isolated from the mangrove endophytic fungus Halorosellinia sp. [14]. The $\mathrm{IC}_{50}$ value of this compound against two human nasopharyngeal epidermoid tumor cell lines (KB and KBv200) was above $50 \mu \mathrm{g} / \mathrm{ml}[14]$.

Bostrycin (3) has a tetrahydroanthraquinone skeleton. 
Related tetrahydroanthraquinone derivatives were produced by fungi such as Alternaria eichhorniae [10], Alternaria porri [15], Alternaria solani [12, 16 19], Auxarthron umbrinum [20], Chrysosporium queenslandicum [21], Dactylaria lutea [22, 23], Dermocybe sp. [24], Phomopsis juniperovora [25], Pleospora sp. [26], and Stemphylium botryosum [27]. The antimicrobial, antiprotozoal, phytotoxic, and cytotoxic activities of these compounds were described by the authors of these papers. The hexahydroanthronol derivatives including two new compounds $\mathbf{1}$ and $\mathbf{2}$ exhibited very weak or no apparent activity in the same and similar bioassays. Therefore, the quinone structure will be necessary for their bioactivities.

Acknowledgements This work was supported in part by Grantin-Aid for Scientific Research on Priority Areas 17035029 from The Ministry of Education, Culture, Sports, Science and Technology (MEXT) of Japan to M. N. We thank Dr. Magie M. Kapojos for her generous help during the sample collection at Manado.

\section{References}

1. Blunt JW, Copp BR, Hu W-P, Munro MHG, Northcote PT, Prinsep MR. Marine natural products. Nat Prod Rep 25: 35-94 (2008) and previous reports in this series.

2. Namikoshi M. Biologically active natural products from marine fungi. In Biomaterials from Aquatic and Terrestrial Organisms. Ed., M. Fingerman and R. Nagabhushanam, pp. 285-359, Science Publishers, Enfield (2006)

3. Bugni TS, Ireland CM. Marine-derived fungi: a chemistry and biologically diverse group of microorganisms. Nat Prod Rep 21: 143-163 (2004)

4. Noda T, Take T, Otani M, Miyauchi K, Watanabe T, Abe J. Structure of bostrycin. Tetrahedron Lett 9: 6087-6090 (1968)

5. Noda T, Take T, Watanabe T, Abe J. The structure of bostrycin. Tetrahedron 26: 1339-1346 (1970)

6. Kelly TR, Saha JK. Bostrycin: structure correction and synthesis. J Org Chem 50: 3679-3685 (1985)

7. Beagly B, Larsen DS, Pritchard RG, Stoodley RJ. Revision of absolute configuration of (-)-bostrycin. J Chem Soc Chem Commun 1989: 17-19 (1989)

8. Furuya K, Shirasaka M. Antibiotics from fungi. IV. Production of rhodosporin (bostrycin) by Nigrospora oryzae. Sankyo Kenkyusho Nempo 21: 165-168 (1969)

9. Van Eijk BW. Bostrycin, a tetrahydroanthraquinone pigment and some other metabolites from the fungus Arthrinium phaeospermum. Experientia 31: 783-784 (1975)

10. Charudattan R, Rao KV. Bostrycin and 4-deoxybostrycin: two nonspecific phytotoxins produced by Alternaria eichhorniae. Appl Environ Microbiol 43: 846-849 (1982)

11. Namikoshi $M$, Negishi $R$, Nagai $H$, Dmitrenok A, Kobayashi H. Three new chlorine containing antibiotics from a marine-derived fungus Aspergillus ostianus collected in Pohnpei. J Antibiot 56: 755-761 (2003)

12. Stoessl A, Stothers JB. Tetrahydroaltersolanol B, a hexahydroanthronol from Alternaria solani. Can J Chem 61: 378-382 (1983)

13. Okamura N, Mimura K, Haraguchi H, Shingu K, Miyahara $\mathrm{K}$, Yagi A. Altersolanol-related compounds from the culture liquid of Alternaria solani. Phytochemistry 42: 77-80 (1996)

14. Xia X-K, Huang H-R, She Z-G, Shao C-L, Liu F, Cai X-L, Vrijmoed LLP, Lin Y-C. 1H and 13C-NMR assignments for five anthraquinones from the mangrove endophytic fungus Halorosellinia sp. (No. 1403). Mag Reson Chem 45: 1006-1009 (2007)

15. Suemitsu R, Horiuchi K, Kubota M, Okamatsu T. Production of alterporriols, altersolanols and macrosporin by Alternaria porri and A. solani. Phytochemistry 29: 1509-1511 (1990)

16. Stoess1 A. Some metabolites of Alternaria solani. Can J Chem 47: 67-76 (1969)

17. Yagi A, Okamura N, Haraguchi H, Abo T, Hashimoto K. Antimicrobial tetrahydroanthraquinones from a strain of Alternaria solani. Phytochemistry 33: 87-91 (1993)

18. Okamura N, Haraguchi H, Hashimoto K, Yagi A. Altersolanol-related antimicrobial compounds from a strain of Alternaria solani. Phytochemistry 34: 1005-1009 (1993)

19. Okamura N, Mimura K, Haraguchi H, Shingu K, Miyahara K, Yagi A. Altersolanol-related compounds from the culture liquid of Alternaria solani. Phytochemistry 42: 77-80 (1996)

20. Alvi KA, Rabenstein J. Auxarthrol A and auxarthrol B: two new tetrahydroanthraquinones from Auxarthron umbrinum. J Ind Microbiol Biotechnol 31: 11-15 (2004)

21. Ivanova VB, Hoshino Y, Yazawa K, Ando A, Mikami Y, Zaki SM Gräfe U. Isolation and structure elucidation of two new antibacterial compounds produced by Chrysosporium queenslandicum. J Antibiot 55: 914-918 (2002)

22. Kettner M, Nemec P, Kovác S, Balanová J. Dactylarin, a new antiprotozoal antibiotic from Dactylaria luea. J Antibiot 26: 692-696 (1973)

23. Becker AM, Rickards RW, Schmalzl KJ, Yick HC. Metabolites of Dactylaria lutea the structures of dactylariol and the antiprotozoal antibiotic dactylarin. J Antibiot 31: 324-329 (1978)

24. Burns CJ, Gill M, Giménez A. Pigments of fungi. XXIV. New trihydroxylated tetrahydroanthraquinones from an Australian fungus belonging to the genus Dermocybe. Aust J Chem 44: 11729-1736 (1991)

25. Wheeler MM, Wheeler DMS, Peterson GW. Anthraquinone pigments from the phytopathogen Phomopsis juniperovora Hahn. Phytochemistry 14: 288-289 (1975)

26. Ge HM, Song YC, Shan CY, Ye YH, Tan RX. New and cytotoxic anthraquinones from Pleospora sp. IFB-E006, an endophytic fungus in Imperata cylindrical. Planta Med 71: 1063-1065 (2005)

27. Assante G, Nasini G. Identity of the phytotoxin stemphylin from Stemphylium botryosum with altersolanol A. Phytochemistry 26: 703-705 (1987) 